Vol. 44, N. 3 : pp. $291-296$, September, 2001

ISSN 1516-8913 Printed in Brazil

\title{
Sightings of Pontoporia blainvillei (Gervais \& D’Orbigny, 1844) and Sotalia fluviatilis (Gervais, 1853) (Cetacea) in South-eastern Brazil
}

\author{
Ana Paula M. Di Beneditto*, Renata Maria A. Ramos and Neuza Rejane W. Lima \\ Universidade Estadual do Norte Fluminense, Centro de Biociências e Biotecnologia, Laboratório de Ciências \\ Ambientais. Av. Alberto Lamego, 2000, Campos - RJ, Brazil
}

\begin{abstract}
Pontoporia blainvillei (Gervais \& D Orbigny, 1844) and Sotalia fluviatilis (Gervais, 1853) have typically coastal habits and are sympatric in South-eastern Brazil. The purpose of this work was to record sightings and describe aspects concerning the behaviour of both species in this region, between 1993 and 1998. The sightings were accomplished by cruises and from a fixed point. Information provided by fishermen were also considered. In general, P. blainvillei was observed in all seasons of the year, up to five nautical miles away from the coast, up to $15 \mathrm{~m}$ deep and the groups comprised up to five specimens. The most part of the groups of S. fluviatilis, were observed in autumm and winter times and comprised up to 10 specimens. In about half of the sightings, the presence of calves and/or juveniles was noted. The cooperative (group) fishing was the foranging behaviour most frequently noted for $\mathrm{S}$. fluviatilis.
\end{abstract}

Key words: Pontoporia blainvillei, Sotalia fluviatilis, sightings, South-eastern Brazil

\section{INTRODUCTION}

Pontoporia blainvillei (Gervais \& D`Orbigny, 1844) and Sotalia fluviatilis (Gervais, 1853) are small cetaceans with typically coastal habits and sympatric in South-eastern Brazil. In this region, both species have been suffering from the impact of the fishing activities, mainly in the North coast of the Rio de Janeiro State $\left(21^{\circ} 35^{`} \mathrm{~S}-22^{\circ} 25^{`} \mathrm{~S}\right)$. They are accidentally caught in all seasons of the year, in gill nets placed up to five nautical miles away from the coastline and up to $20 \mathrm{~m}$ deep (Di Beneditto et al., 1998).

The North coast of the Rio de Janeiro State is permanently influenced by the Paraíba do Sul river
(Meuhe \& Valentini, 1998). In principle, the limitations resulting from the reduction in the water transparency and the presence of waves (Beaufort scale >2) may bring difficulty to the observation of aquatic animals. However, as the estuarine regions represent a source of trophic resources for small coastal cetaceans (Borobia et al., 1991), it is a favorable region to carry out studies about the behavior of such animals.

The purpose of this work was to record sightings and describe aspects concerning the behavior of $P$. blainvillei and $S$. fluviatilis in South-eastern Brazil, especially in the North coast of the Rio de Janeiro State, where these species have been accidentally caught in fishing activities.

\footnotetext{
* Author for correspondence
} 


\section{MATERIALS AND METHODS}

Three methods were used for the observation of dolphins: (I) cruises between Atafona (21035`S) and Macaé $\left(22^{\circ} 25^{\circ} \mathrm{S}\right)$, (II) observation from a fixed point in Atafona beach and (III) compilation of the information provided by fishermen (Fig.1).

Method I: The cruises were made monthly, between April and December 1993. Each cruise lasted 2 to 3 days. The boat moved parallel to the coast, navigating between 0.5 and 3 nautical miles away, ranging from 5 to $12 \mathrm{~m}$ deep. Two of the authors (A.P.M. Di Beneditto and R.M.A. Ramos) were present in all cruises.

Method II: The observations from a fixed point in Atafona beach, situated $20 \mathrm{~m}$ away from the surfzone and $5 \mathrm{~m}$ up to the sea level, were made from July 1994 to October 1997. The sightings were made by one of the authors (A.P.M. Di Beneditto), from 8:00 to 12:00 a.m., covered periods that ranged from 12 to 24 days each month.

In the both methods described above, a binocular was used for the observation of dolphins.

Method III: The information provided by fishermen was considered only for $P$. blainvillei. This specie is easily distinguished due to the brownish body colouration pattern and the long rostrum. Information about $S$. fluviatilis were not considered because it could be confused with other delphinids that presented a similar body colouration pattern, such as Tursiops truncatus (Montagu, 1821) and Stenella frontalis (Cuvier, 1828) juveniles. These fishermen were spread over around $40 \%$ of the 145 boats based in Atafona village. The fishing gear used by them were bottom trawl nets, gill nets and handlines. The fishing ground extended from Atafona to Macaé (Fig.1), from within one to 60 nautical miles off-shore, covers about $20,000 \mathrm{Km}^{2}$. The information about sighting of dolphins was obtained through interviews made weekly by the authors, between January 1995 to December 1998.

The information obtained through the three observation methods was analyzed in relation to: (i) seasonatity of occurrence, (ii) area of observation (i.e. distance from the coastline and depth), (iii) density of the groups, (iv) presence of calves and/or juveniles and (v) behavior pattern (i.e.: movement, foraging).
For $S$. fluviatilis, the specimens whose body length corresponded up to $2 / 3$ of the length of the body of adult individuals, i.e., specimens of up to $130 \mathrm{~cm}$ approximately, were considered calves and/or juveniles. However, for $P$. blainvillei this kind of consideration was difficult to be done, especially by the fishermen.

In order to analyze the behavior patterns of $P$. blainvillei and $S$. fluviatilis, the information indirectly obtained through the observation of tooth marks on the body of accidentally caught specimens in the region, was also considered. The tooth marks made by conspecifics were distinguished as white and thin parallel lines on the skin. The distance between each line was the same between each teeth of the dolphin specie.

The Chi-square test $\left(\chi^{2}\right)$ (Siegel, 1975) was applied to test the significance of the differences between the frequencies of seasonality of the species occurrence. In order to check the relationship between the quantity of $S$. fluviatilis groups observed in Atafona beach and the number of calves and/or juveniles in each group with the density, the Spearman $\left(\mathrm{r}_{\mathrm{s}}\right)$ correlation test was applied (Siegel, 1975).

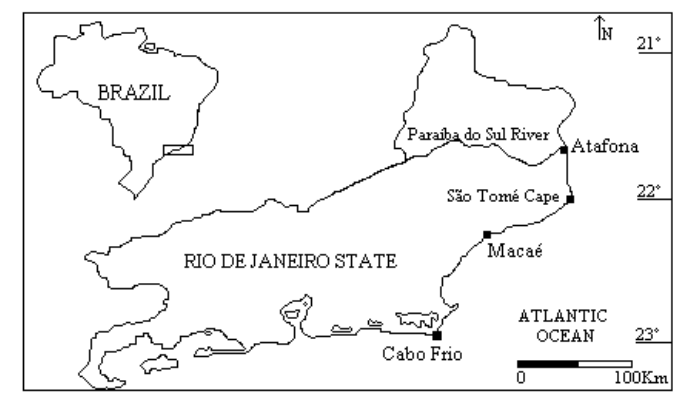

Figure 1 - Rio de Janeiro State, indicating the sighting area in the North coast.

\section{RESULTS}

Between May 1993 and October 1998, there were 36 sightings of $P$. blainvillei and $91.7 \%$ of the total were made by the fishermen (Table 1). The unequal number of sightings made directly by the authors and by the fishermen was due to the greatest observation effort of the latter. The fishermen stayed on board from eight to $24 \mathrm{~h} /$ day, from 16 to 24 days each month. Moreover, the fishermen had a 
large observation area in comparison with the authors.

The groups observed comprised one to 15 specimens. In general, the groups presented low density because $77.8 \%$ of them had up to five specimens (Table 1).

The sightings were made in areas near the coast and $91.7 \%$ of the total were obtained up to five nautical miles away, up to $15 \mathrm{~m}$ deep (Table 1). In relation to the behavior, the $P$. blainvillei species moved during most part of the sightings and on three occasions specimens were seen to be foraging.
The frequency of occurrence of $P$. blainville $i$ was the same between spring and summer times (October until March) and autumm and winter times (April until September). There were 18 sightings in both times (Table 1).

The analysis of the presence of marks in the body could be made in 94 specimens of $P$. blainvillei accidentally caught in the North of the Rio de Janeiro State, between 1989 and 1998. From this total, conspecifics tooth marks in around $26.6 \%$ of the specimens were noted.

Table 1 - Sightings of Pontoporia blainvillei in the North coast of the Rio de Janeiro State, through the three observation methods (I: cruises; II: fixed point; III: information provided by fishermen).

\begin{tabular}{|c|c|c|c|c|c|c|}
\hline Area & Latitude & Date & $\begin{array}{c}\text { Coast distance } \\
\text { (nautical miles) }\end{array}$ & $\begin{array}{c}\text { Depth } \\
\text { (meters) }\end{array}$ & $\begin{array}{c}\text { Number of } \\
\text { dolphins }\end{array}$ & Method \\
\hline \multirow[t]{10}{*}{ Atafona } & $\left(21^{\circ} 35^{\prime} \mathrm{S}\right)$ & Mar/95 & 0,1 & 5 & 1 & III \\
\hline & & Aug/95 & $<0,1$ & 3 & 2 & II \\
\hline & & Aug/95 & 0,1 & 5 & 2 & III \\
\hline & & Aug/96 & 0,1 & 5 & 1 & III \\
\hline & & Sep/96 & 19,0 & 21 & 3 & III \\
\hline & & Apr/97 & 22,6 & 25 & 2 & III \\
\hline & & May/97 & 0,2 & 5 & 2 & III \\
\hline & & Jul/97 & 0,2 & 5 & 8 & III \\
\hline & & Nov/97 & 0,2 & 5 & 4 & III \\
\hline & & Oct/98 & 5,0 & 15 & 8 & III \\
\hline \multirow[t]{5}{*}{ Grussaí } & $\left(21^{\circ} 40^{\prime} \mathrm{S}\right)$ & Feb/95 & 0,5 & 7 & 4 & III \\
\hline & & $\mathrm{Feb} / 95$ & 0,4 & 7 & 10 & III \\
\hline & & Apr/95 & 0,9 & 9 & 3 & III \\
\hline & & Nov/95 & 0,5 & 7 & 3 & III \\
\hline & & Jul/96 & 3,2 & 12 & 2 & III \\
\hline \multirow[t]{6}{*}{ Iquipari } & $\left(21^{\circ} 45^{\prime} \mathrm{S}\right)$ & May/93 & 1,6 & 10 & 3 & I \\
\hline & & $\mathrm{Jul} / 95$ & 0,2 & 6 & 1 & III \\
\hline & & Oct/96 & 4,3 & 15 & 2 & III \\
\hline & & $\mathrm{Jan} / 97$ & $<0,1$ & 5 & 4 & III \\
\hline & & $\mathrm{Feb} / 97$ & 0,6 & 7 & 2 & III \\
\hline & & Oct/98 & 2,2 & 11 & 10 & III \\
\hline \multirow[t]{5}{*}{ Açu } & $\left(21^{\circ} 50^{\prime} \mathrm{S}\right)$ & Oct/93 & 1,6 & 14 & 1 & I \\
\hline & & Feb/95 & 0,2 & 8 & 5 & III \\
\hline & & May/96 & 2,2 & 15 & 3 & III \\
\hline & & Mar/97 & 0,1 & 7 & 10 & III \\
\hline & & Aug/98 & 0,2 & 8 & 15 & III \\
\hline \multirow[t]{4}{*}{ São Tomé Cape } & $\left(22^{\circ} 00^{\prime} \mathrm{S}\right)$ & Mar/95 & 1,0 & 8 & 2 & III \\
\hline & & Sep/95 & 9,7 & 14 & 1 & III \\
\hline & & Mar/96 & 1,0 & 8 & 4 & III \\
\hline & & Jul/96 & 3,2 & 11 & 2 & III \\
\hline \multirow[t]{4}{*}{ Farol de São Tomé } & $\left(22^{\circ} 05^{\prime} \mathrm{S}\right)$ & Jul/95 & 0,2 & 5 & 2 & III \\
\hline & & Mar/97 & $<0,1$ & 4 & 3 & III \\
\hline & & Sep/97 & 1,0 & 8 & 6 & III \\
\hline & & Nov/97 & 0,3 & 5 & 10 & III \\
\hline Barra do Furado & $\left(22^{\circ} 07^{\prime} S\right)$ & Mar/95 & 2,0 & 12 & 2 & III \\
\hline Quissamã & $\left(22^{\circ} 20^{\prime} \mathrm{S}\right)$ & Jul/97 & $<0,1$ & 6 & 5 & III \\
\hline
\end{tabular}


During the cruises, there were $13 \mathrm{~S}$. fluviatilis sightings (Table 2). Around $85 \%$ of the groups observed had up to 15 specimens; on two occasions groups with approximately 50 animals were sighted (Table 2). The presence of calves and/or juveniles was always noted in groups of more than 10 specimens. The movement and/or foraging behaviors were observed in all sightings.

The frequency of occurrence of $S$. fluviatilis observed through the cruises did not vary significantly between the seasons $\left(\chi^{2}=1.92\right.$; d.f. $=$ $1 ; P>0.05)$.

Table 2 - Sightings of Sotalia fluviatilis in the North coast of the Rio de Janeiro State, through the cruises.

\begin{tabular}{lccccc}
\hline Area & Latitude & Date & $\begin{array}{c}\text { Coast distance } \\
\text { (nautical miles) }\end{array}$ & $\begin{array}{c}\text { Depth } \\
\text { (meters) }\end{array}$ & $\begin{array}{c}\text { Number of } \\
\text { dolphins }\end{array}$ \\
\hline Grussaí & $\left(21^{\circ} 40^{\prime} \mathrm{S}\right)$ & $\mathrm{Dec} / 93$ & 1,6 & 9 & 7 \\
Iquipari & $\left(21^{\circ} 50^{\prime} \mathrm{S}\right)$ & $\mathrm{Dec} / 93$ & 0,5 & 5 & 6 \\
Farol de São Tomé & $\left(22^{\circ} 05^{\prime} \mathrm{S}\right)$ & $\mathrm{Apr} / 93$ & 1,0 & 6 & 15 \\
& & $\mathrm{Apr} / 93$ & 2,6 & 11 & 50 \\
& & $\mathrm{May} / 93$ & 1,6 & 8 & 12 \\
& & $\mathrm{Sep} / 93$ & 1,6 & 8 & 50 \\
Barra do Furado & & $\mathrm{Dec} / 93$ & 0,5 & 5 & 3 \\
& \multirow{2}{*}{$\left(22^{\circ} 07^{\prime} \mathrm{S}\right)$} & $\mathrm{Apr} / 93$ & 1,0 & 8 & 10 \\
& & $\mathrm{May} / 93$ & 1,6 & 9 & 6 \\
Flecheira & & $\mathrm{Aug} / 93$ & 1,0 & 8 & 8 \\
& & $\mathrm{Oct} / 93$ & 1,6 & 9 & 2 \\
\hline
\end{tabular}

During 40 months, observations were made on the behavior of $S$. fluviatilis from a fixed point in Atafona beach. In total, 302 groups and 1,938 specimens were sighted.

The density of each group varied from one to 30 specimens and $86.4 \%$ of the groups comprised up to 10 specimens. A negative but significant correlation $\left(r_{s}=-0.65\right.$; d.f. $\left.=17 ; P \leq 0.05\right)$ was noted between the quantity of groups and the number of specimens in each group, indicating that the groups of $S$. fluviatilis with relatively low density were more commonly sighted. The frequency of days in which the dolphins were sighted varied significantly between the seasons $(\chi$ ${ }^{2}=6.12$; d.f. $\left.=1 ; P \leq 0.05\right)$. In spring and summer times, the number of days without sighting was two times higher (Table 3).

Table 3 - Observation effort of Sotalia fluviatilis in the North coast of the Rio de Janeiro State, by seasons, through the fixed point.

\begin{tabular}{lccc}
\hline Seasons & $\begin{array}{c}\text { Days with } \\
\text { sighting }\end{array}$ & $\begin{array}{c}\text { Days without } \\
\text { sighting }\end{array}$ & $\begin{array}{c}\text { Total } \\
\text { effort }\end{array}$ \\
\hline Spring/Summer & 126 & 252 & 378 \\
Autumn/Winter & 176 & 242 & 418 \\
All seasons & 302 & 494 & 796 \\
\hline
\end{tabular}

In about half of the sightings of S. fluviatilis, the presence of calves and/or juveniles was noted. The density varied between one and five individuals in each group of adult members. The relationship between the number of calves and/or juveniles and the total number of specimens in the groups observed was positive and significant $\left(\mathrm{r}_{\mathrm{s}}=0.55\right.$; d.f.. $=148 ; P \leq 0.05$ ), which indicated that the number of calves and/or juveniles in each group was directly proportional to the density.

The frequency of groups with and without calves and/or juveniles did not vary significantly between the seasons $\left(\chi^{2}=0.51\right.$; d.f. $\left.=1 ; P>0.05\right)$ (Table 4$)$.

Table 4 - Sightings of calves and/or juveniles of Sotalia fluviatilis in the North coast of the Rio de Janeiro State, by seasons, through the fixed point.

\begin{tabular}{lccc}
\hline Seasons & $\begin{array}{c}\text { Groups with } \\
\text { calves and/or } \\
\text { juveniles }\end{array}$ & $\begin{array}{c}\text { Groups without } \\
\text { calves and/or } \\
\text { juveniles }\end{array}$ & Total \\
\hline Spring/Summer & 66 & 60 & 126 \\
Autumn/Winter & 84 & 92 & 176 \\
All seasons & 150 & 152 & 302 \\
\hline
\end{tabular}

At Atafona beach, the cooperative (group) fishing was the foraging behavior most frequently noted for $S$. fluviatilis. During the cooperative fishing, the 
animals leaped randomly and sequentially.

The analysis of the presence of marks in the body could be made in 70 specimens of $S$. fluviatilis conspecifics tooth marks were noted in around $42.4 \%$ of the specimens.

\section{DISCUSSION}

The present sightings of $P$. blainvillei were the first observation records in its habitat in South-eastern Brazil. The sightings of this specie are difficult due to the small body size, low density of the group and absence of aerial behaviour, like jumps (Jefferson et al., 1993). The density of the P. blainvillei groups, sighted in the North coast of the Rio de Janeiro State followed the same pattern noted in other areas of its distribution (Pinedo, 1994; Crespo et al., 1998; Bordino et al., 1999).

In Argentina, $P$. blainvillei sightings in the areas near the coast are frequent during spring and summer times. The movement of this species is associated with the water temperature and the prey movement; in winter, the groups usually go away from the coast (Bordino et al., 1999). However, this moving pattern was not observed in the North coast of the Rio de Janeiro State, because sightings in the areas near the coast were recorded in all seasons of the year.

The seasonal differences in the movement patterns may be related to two nonexcludent factors. First, the temperature difference of the water surface between the distribution areas of this specie may affect the seasonality of occurrence. In the Cabo Frio region $\left(22^{\circ} 55^{\prime} S\right.$ ) (Fig.1), the Central South Atlantic Water (CSAW) upwelled onto the self and the temperature of the water surface in coastal areas remains lower than $20^{\circ} \mathrm{C}$ in the spring and summer times (Valentim \& Monteiro-Ribas, 1993). However, the region from Atafona to São Tomé Cape $\left(22^{\circ} 00^{\prime} S\right.$ ) (Fig.1), where $83.3 \%$ of the sightings of $P$. blainvillei were made, is strongly influenced by the Paraíba do Sul River discharge and the temperature of the water surface was around $24^{\circ} \mathrm{C}$ in all seasons (Muehe \& Valentini, 1998; Souza et al., 1998). Secondly, there may be variation in the availability and/or movement of the prey preferably consumed by $P$. blainvillei throughout its distribution area.

The observation of conspecifics tooth marks on the body of $P$. blainvillei specimens accidentally caught could be related to the rescue attempt by one or more members of the group. This confirms accidentally caught in the North of the Rio de Janeiro State between 1989 and 1998. The the literature data according to which the species has epimeletic or care-giving behavior (Pilleri, 1984). The conspecifics tooth marks were also observed in S. fluviatilis specimens. However, the intra-specific aggressive behavior displayed by the adult specimens (da Silva \& Best, 1996) made it difficult to interpret the possible causes responsible for such marks.

The observations of $S$. fluviatilis in the North of the Rio de Janeiro State indicated that this specie maintained the same density of the group and behavioral pattern of other areas (Geise, 1989; Monteiro-Filho, 1991). Only the seasonality of occurrence in Atafona beach was different and, could be related with the availability and/or movement of the prey consumed by the specie in the area.

The sightings of calves and/or juveniles of $S$. fluviatilis, made in all seasons of the year suggested that there might not be a defined reproductive period for the specie in the area. However, the environmental features, such as distance, water turbulence and turbidness did not help differentiating calves from juveniles.

The direct relation between the number of calves and/or juveniles and the density of the groups indicated that females and their offsprings did not leave the group, which confirmed the gregarius habit of this specie (Jefferson et al., 1993; da Silva \& Best. 1996).

The results of the present study and the analysis of the relationship between the fishing activity and these dolphins, performed by Di Beneditto et al. (1998) indicated that P. blainvillei and S. fluviatilis were common species in the study area. Probably, they are coexisting with low competition for the trophic resources. However, the analysis of the feeding ecology of these dolphins would be important to confirm this hypothesis.

\section{ACKNOWLEDGEMENTS}

We would like to express our deepest gratitude to Salvatore Siciliano, Ilana Rosental Zalmon and an anonymous referee for critical review on this manuscript; to the fishermen from Atafona village 
who provide us with information about $P$. blainvillei and with the accidentally caught dolphins for the tooth marks analysis and; to the Petróleo Brasileiro S/A - PETROBRAS for financial support. A.P.M. Di Beneditto and R.M.A. Ramos acknowledge the fellowship support from FENORTE.

\section{RESUMO}

Pontoporia blainvillei (Gervais \& D'Orgigny, 1844) e Sotalia fluviatilis (Gervais, 1853) possuem hábitos tipicamente costeiros e são simpátricas no Sudeste do Brasil. O objetivo deste trabalho foi registrar avistagens e descrever aspectos relacionados ao comportamento de ambas as espécies na região, entre 1993 e 1998. As avistagens foram realizadas através de cruzeiros e ponto fixo. Informações fornecidas por pescadores também foram consideradas. Em geral, $P$. blainvillei foi observada em todas as estações do ano, a até cinco milhas náuticas de distância da linha da costa e $15 \mathrm{~m}$ de profundidade e, os grupos eram formados por até cinco espécimens. A maior parte dos grupos de $S$. fluviatilis foi observada no período de outono e inverno e, era formada por até 10 espécimens. Em metade das avistagens, a presença de filhotes e/ou juvenis foi verificada. A pesca cooperativa (em grupo) foi o comportamento alimentar observado com maior freqüência para $S$. fluviatilis.

\section{REFERENCES}

Bordino, P.; Thompson, G. and Iñíguez, M. (1999), Ecology and behaviour of the franciscana (Pontoporia blainvillei) in Bahía Anegada, Argentina. J. Cetacean Res. Manage., 1(2), 213-222

Borobia, M.; Siciliano, S.; Lodi, L. and Hoek, W. (1991), Distribution of the south american dolphin Sotalia fluviatilis. Can. J. Zool. 69, 1025-1039

Crespo, E.A; Harris, G. and González, R. (1998), Group size and distributional range of the franciscana, Pontoporia blainvillei. Mar. Mam. Sci. 14(4), 845-849
Di Beneditto, A. P.; Ramos, R. and Lima, N. R. W. (1998), Fishing activity in Northern Rio de Janeiro State (Brazil) and its relation with small cetaceans. Braz. Arch. Biol. Tech. 41(3), 296-302

Jefferson, T. A., Leatherwood, S. and Webber, M. A. (1993), Marine mammals of the world, ed. FAO, Rome, 320p

Geise, L. (1989), Estrutura Social, comportamental e populacional de Sotalia sp (Gray, 1886) (Cetacea, Delphinidae) na região estuarino-lagunar de Cananéia, SP e na Baía de Guanabara, RJ. MSc. Thesis, Universidade de São Paulo, São Paulo, Brazil.

Monteiro-Filho, E. L. A. (1991), Comportamento de caça e repertório sonoro do golfinho Sotalia brasiliensis (Cetacea: Delphinidae) na região de Cananéia, Estado de São Paulo. PhD. Thesis, Universidade Estadual de Campinas, Campinas, Brazil.

Muehe, D. and Valentini, E. (1998), O litoral do Estado do Rio de Janeiro: uma caracterização físico-ambiental. ed. FEMAR, Rio de Janeiro, 99p.

Pilleri, G. (1984), Epimeletic behaviour in Cetacea: intelligent or instinctive ? In- Investigations on Cetacea, ed. G. Pilleri. University of Berne, Berne, 16, 30-47

Pinedo, M. C. (1994), Review of small cetacean fishery interactions in southern Brazil with special reference to the franciscana, Pontoporia blainvillei. Rep. Int. Whal. Commn., 15, 251-259

Siegel, S. (1975), Estatística não-paramétrica para as ciências do comportamento. ed. McGraw-Hill Ltda., São Paulo, 350p

Silva, V. M. and Best, R. C. (1996), Sotalia fluviatilis. In- Mammalian Species, ed. G.N. Cameron, A V. Linzey, E. Anderson and K.F. Koopman. American Society of Mammalogists, Washington. 527, 1-7

Souza, E. G. A.; Silva, C. F.; Pereira, E. A. and Zalmon, I. R. (1998), A influência de parâmetros ambientais na distribuição temporal de peixes capturados em recife artificial (S. Francisco de Itabapoana, RJ). Paper presented at IV Simpósio de Ecossistemas Brasileiros, 20-25 April, Águas de Lindóia, São Paulo.

Valentin, J. L. and Monteiro-Ribas, W. M. (1993), Zooplankton community structure on the Eastsoutheast Brazilian continental shelf $\left(18^{\circ}-23^{\circ} \mathrm{S}\right)$. Cont. Shelf Res., 13(4), 407-424

Received: September 10, 1999; Revised: May 22, 2000; Accepted: December 01,2000. 